\title{
A Research of the Construction Project Managers' Moral Qualities
}

\author{
CuiChenhua \\ xianyang vocational and technical college \\ xianyang, China \\ E-mail :chenhua_751005@163.com
}

\begin{abstract}
In view of non-standard question of the current construction project managers' "moral" qualities structure, this article investigated, studied and analyzed domestic and foreign structure of construction project managers' "moral" qualities. referring to the domestic and foreign existing qualities structure model; At the same time the author enters the construction site, construction manager projects department, construction related industry sectors and communicated in different degrees with all kinds of people. By contrast, abstraction and summary, the author creates a construction enterprise project managers' "moral" qualities structure framework ; By means of questionnaires and other means, the author builds out of the importance of each kind of qualities element for project success ; Finally, the feasibility of the scheme is verified by practical application.
\end{abstract}

Key-expressions: construction project manager; political qualities; ideological qualities; personal character qualities; professional moral qualities

\section{INTRODUCTION}

The discussion on construction project managers' moral qualities is very much at home and abroad, but the discussion on " moral" qualities structure establishment is rarely reported. The main points of view are the following: In The Discussion on The Project Manager's Qualities in Project Management, Zhang Guishan thought, "Very high political, ideological quality and noble character. Adhere to maintenancing the interests of society, company, owners and the construction team." In Brief Discussion on The Construction Enterprise Project Manager's Qualities and Cultivations, Zang Hong thought, "The most basic occupation moral is to be loyal to the overall interests of the organization team." In Brief Discussion on The Construction Project Manager's Qualities, Yang Leiping thought, "We should adhere to one center and two basic points; with a high sense of responsibility and professionalism, perseverance, and have the courage to forge ahead." [1]

\section{THE ANALYSIS OF THE STRUCTURE ON CONSTRUCTION PROJECT MANAGERS' "MORAL”QUALITIES}

\section{A. Political qualities}

Political qualities is in the premise and basic position in the quality structure system; It is the cornerstone of the leadership, and is also an overall quality by manipulation. If the political qualities are strong, work will be handy, subordinates will support. Therefore, the project managers must have the correct political quality, so as to correctly guide the whole process of project management ideas, put an end to depart from the fundamental principle. The political qualities are the most important link in the selection of project manager. [2]

\section{B. Ideological qualities}

Ideological qualities's level is a touchstone whether the project managers are mature, it is the essence of the project managers, it is of great significance for performing the leadership role. Ideological qualities is not up to the standard, it is difficult to form a good political qualities ; high level of cultural knowledge and inferior ideological quality, in the process of performing of the

This paper is interim results of 《Research on the construction of project managers'quality structure in Building construction》 of Xianyang Vocational and Technical College's 2014 Annual Scientific research fund project ( No. 2014KYC04) 
leadership role, it is also very difficult to achieve the desired achievement; If ideological qualities is poor, leading function is lost. [3]

\section{Personal character qualities}

Personal character qualities is the spiritual connotation which the project managers come into being in the process of work, life and study, it regulates the relationship with others 、 it is replete with the value content and the subjective orientation; It is an important part of the project managers' personality . [4]

\section{Professional moral qualities}

It refers that the project managers should have the professional code of conduct and specifications which reflect the professional features and adjust a certain professional relationships in the process of working activities. [5]

\section{EMPIRICAL EXPLORATION}

Considering the questionnaire survey object should not have any benefit, the skirt belt, the dispute, the contradictory relations with project manager, so people make Bidding companies, consulting firms, assets and credit rating companies, engineering and technology consulting firm, supervision companies, accounting firms, law firms, the building housing departments of Xianyang City and the various county as the survey object, let the respondents evaluate the relations of project manager's "moral" quality and the project success in construction enterprise. In the survey on the project manager's "moral" quality lists 12 indicators (TABLEI), there are four options for each indicator, From "1 does not approve of very much", "2 does not approve of”, "3 approvals" “4 approves of very much", asked respondents referring to the status quo that they are engaged in work to fill in the questionnaire. [6]

The planning and design of this investigation and study is clever. Its organization is strict and orderly the investigation and study developed very much smoothly. Respectively draw 20 units at random from fixed telephone number yellow pages and list the above 7 companies and offices in Xianyang area of Shanxi province; the building housing departments of Xianyang City and the various county had 14 units, providing 2 questionnaire tables for each unit, a total of 308 questionnaires are distributed. Required respondents more than 5 years experience in the construction industry. The survey was conducted from June to October in 2014, finally recovered 245 valid questionnaires, the rate of recovery was $80 \%$.

\section{TABLE I. QUESTIONNAIRE}

Serial Quality indicators

number

1 working closely and fully national fundamental policy

2 compaction control, performance competition

3 contributing to the overall situation

4 combating corruption and building a clean organization,

5 the spirits of "Create" and " Struggle hard"

6 strengthening the theoretical accomplishment

7 ideological style、idea

8 "out-and-out" honesty

9 pursuit of quality, being focused on ensuring security

10 dedication

11 democratic decision-making

12 frugal running an business 、 advocating savings
Score ( 1 does not approve of very much, 2 does not approve of, 3 approvals ,4 approves of very much) Single item choice 
In order to validate the credibility of questionnaire and effectively extract common elements, using SPSS software adopts principal component and variance maximum orthogonal rotation method to analysis factor, get a clear structure of the following four factors: factor1: serial number $1,3,5$; factor2: serial number 6,7 ; factor3: serial number 8,10,11,12 and factor4: serial number 2,4,9. According to TABLE I., Find the 4 factors respectively representing: political qualities, ideological qualities, personal character qualities and professional moral qualities. [7]

TABLE II. CORRELATION ANALYSis OF ProJECT MANAGER'S " MORAL " QUALITIES AND SUCCESS OF THE PROJECT

\begin{tabular}{|c|c|c|c|c|c|c|}
\hline & & $\begin{array}{l}\text { Project } \\
\text { success }\end{array}$ & $\begin{array}{l}\text { political } \\
\text { qualities }\end{array}$ & $\begin{array}{l}\text { Ideological } \\
\text { qualities }\end{array}$ & $\begin{array}{l}\text { Personal } \\
\text { character } \\
\text { qualities }\end{array}$ & $\begin{array}{l}\text { professional moral } \\
\text { qualities }\end{array}$ \\
\hline Project & Pearson correlation & 1 & $0.158(*)$ & $0.185(*)$ & $0.245(* *)$ & $0.196(* *)$ \\
\hline success & $\begin{array}{l}\text { Significance(Double } \\
\text { tail) }\end{array}$ & 0 & 0.019 & 0.015 & 0.000 & 0.002 \\
\hline \multirow{5}{*}{ political qualities } & Sample size & 245 & 244 & 244 & 244 & 244 \\
\hline & Pearson correlation & 0.158 & 1 & $0.201(* *)$ & $0.577(* *)$ & $0.547(* *)$ \\
\hline & & $(*)$ & & & & \\
\hline & $\begin{array}{l}\text { Significance(Double } \\
\text { tail) }\end{array}$ & 0.019 & 0 & 0.000 & 0.000 & 0.000 \\
\hline & Sample size & 244 & 244 & 244 & 243 & 243 \\
\hline \multirow[t]{3}{*}{ Ideological qualities } & Pearson correlation & $\begin{array}{c}0.185 \\
(*)\end{array}$ & $0.201(* *)$ & 1 & $0.186(* *)$ & $0.167(* *)$ \\
\hline & $\begin{array}{l}\text { Significance(Double } \\
\text { tail) }\end{array}$ & 0.015 & 0.000 & 0 & 0.000 & 0.000 \\
\hline & Sample size & 244 & 244 & 244 & 243 & 243 \\
\hline \multirow[t]{3}{*}{$\begin{array}{l}\text { Personal } \\
\text { qualities }\end{array}$} & Pearson correlation & $\begin{array}{r}0.245 \\
(* *)\end{array}$ & $0.577(* *)$ & $0.186(* *)$ & 1 & $0.661(* *)$ \\
\hline & $\begin{array}{l}\text { Significance(Double } \\
\text { tail) }\end{array}$ & 0.000 & 0.000 & 0.000 & 0 & 0.000 \\
\hline & Sample size & 244 & 243 & 243 & 243 & 243 \\
\hline \multirow[t]{3}{*}{$\begin{array}{l}\text { professional moral } \\
\text { qualities }\end{array}$} & Pearson correlation & $\begin{array}{r}0.196 \\
(* *)\end{array}$ & $0.547(* *)$ & $0.167(* *)$ & $0.661(* *)$ & 1 \\
\hline & $\begin{array}{l}\text { Significance(Double } \\
\text { tail) }\end{array}$ & 0.002 & 0.000 & 0.000 & 0.000 & 0 \\
\hline & Sample size & 244 & 243 & 243 & 243 & 243 \\
\hline
\end{tabular}

Notes: (1)** Indicates that the 0.01 level statistics on significant(Double tail) ; (2) * Indicates that the 0.05 level statistics on significant(Double tail) . based on the formula is as follows

$$
\rho_{X, Y}=\frac{N \sum X Y-\sum X \sum Y}{\sqrt{\left.N \sum X^{2}-\sum X\right)^{2}} \sqrt{N \sum Y^{2}-\left(\sum Y\right)^{2}}}
$$

The correlation of various factors and project success engaged in project, the same as below). Discover, professional moral 、 Personal character qualities and success of the project has significant correlation at 0.01 level, ideological, political qualities and success of the project has a significant correlation at the 0.05 level, while each " moral " quality mutual significant correlation at 0.01 level. [8]

provided in TABLE II (notes: project success is the obtained conclusion that respondents evaluate actually 
TABLE III. DESCRIPTIVE STATISTICS OF " MORAL " QUALITY

\begin{tabular}{|c|c|c|c|c|c|}
\hline & $\begin{array}{l}\text { sample } \\
\text { size }\end{array}$ & $\begin{array}{l}\text { Minimum } \\
\text { value }\end{array}$ & $\begin{array}{l}\text { Maximum } \\
\text { value }\end{array}$ & The mean & $\begin{array}{l}\text { Standard } \\
\text { deviation }\end{array}$ \\
\hline political qualities & 245 & 1.00 & 4.00 & 2.8634 & 0.49376 \\
\hline Ideological qualities & 245 & 1.50 & 4.00 & 2.8468 & 0.46740 \\
\hline $\begin{array}{l}\text { Personal character } \\
\text { qualities }\end{array}$ & 245 & 1.50 & 4.00 & 2.7234 & 0.47563 \\
\hline professional moral & 245 & 1.50 & 4.00 & 2.7012 & 0.47213 \\
\hline
\end{tabular}

qualities

Effective sample size $\quad 243$

Notes: based on the formula is as follows

$$
\begin{aligned}
\mu & =\frac{1}{N} \sum_{i=1}^{N} x_{i} \\
\sigma & =\sqrt{\frac{1}{N} \sum_{i=1}^{N}\left(x_{i}-\mu\right)^{2}} \text { TABLE III shows }
\end{aligned}
$$

the average number of each quality, between 1 and 4 points 2.5 is regarded as the middle value of judging performance advantages and disadvantages. In general,

each quality is very critical. For more in-depth research project manager "moral" of various qualities on the role of project success, all the projects are classified as "successful" (contained is evaluated as "successful" and "very successful" project)and "Unsuccessful” (Including evaluated as "normal" , "failure" and "failed miserably " project) group 2 . [9]

TABLE IV. INDEPENDENT SAMPLE T-TEST

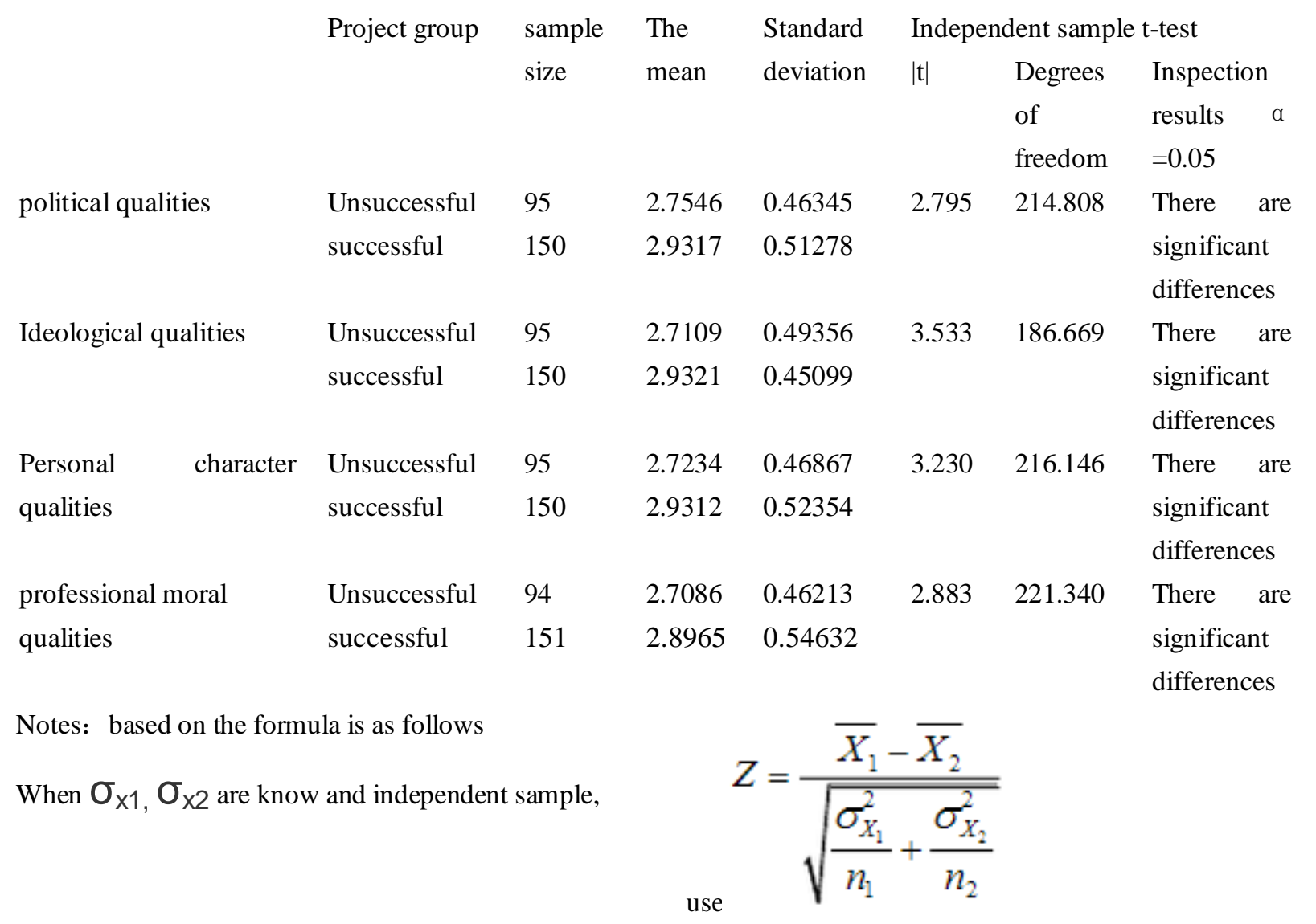




$$
f=\frac{\left(\frac{s_{1}^{2}}{n_{1}}+\frac{s_{2}^{2}}{n_{2}}\right)^{2}}{\frac{\left(s_{1}^{2} / n_{1}\right)^{2}}{n_{1}-1}+\frac{\left(s_{2}^{2} / n_{2}\right)^{2}}{n_{2}-1}}
$$

In two groups of

successful and unsuccessful projects, project manager's professional moral qualities and Personal character qualities are remarkable different, Ideological qualities and political qualities also have the obvious difference. [10]

\section{CONCLUSIONS}

Through the above statistical exploration, obtains the following conclusion: firstly ,the professional moral qualities is most important for project success, Secondly , according to the importance Respectively is in turn the personal character qualities 、 the ideological qualities 、 the political qualities. The conclusion and a lot of this aspect of academic papers 、 writing reach coincides without previous consultation. Thus it can be seen the key to project success is to stick to project manager's professional moral ( Namely profession stipulation) qualities; Then obviously need to adhere to the personal character qualities, because personal character qualities defines and constrains other qualities, and stipulats and designs other qualities developed and displayed way、 method fate and finality, also shows and reflects the style and grade of the overall qualities, the personal character qualities has developed into a extraordinary tools and standards which manage the right、 maintain justice、shape society model and pave correct life path. Finally, In view of the ideological qualities the political qualities, the project managers should often grasp unremittingly, keep pace with the times, often for ever new, only in this way, can achieve the project, perfect life.This conclusion has been generally trial in Shaanxi Province, It has had a profound effect and significance Specific approach for the selection and training of project managers in construction companies. The specific practice is that the morality part o $\mathrm{f}$ a selecting test should be setted the items from more to 1 ess based on the important degree of all quality elements $t$ o the project's success from large to small. In the course and class periods settings of training project manager, the contents and class periods are also designed from more to less accordin $\mathrm{g}$ to the important degree of all quality elements to the proj ect's success from large to small. It makes people very excited

that the feedback news which is given by $90 \%$ constructio $\mathrm{n}$ enterprises from the whole province.
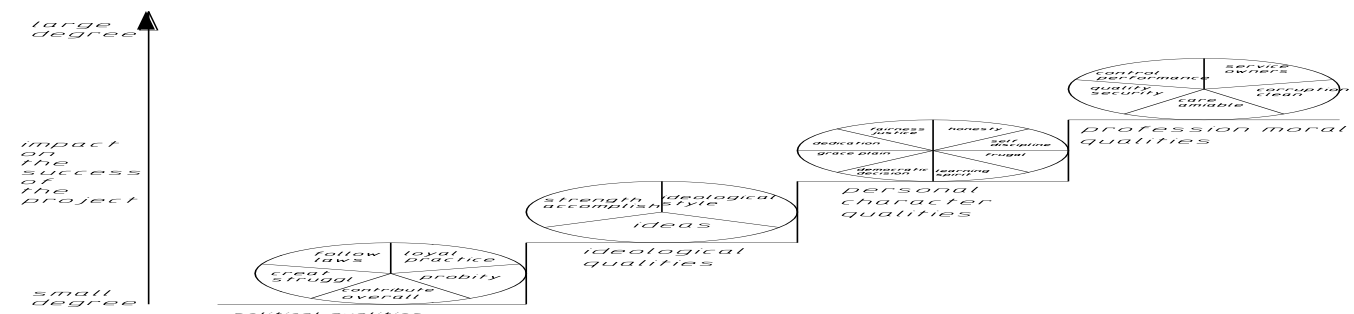

\section{REFERENCES}

[1] gaozhuangyong.the discussion on how to improve the execution of the project leader's the self-discipline[J].china Railway 20th Bureau Group Co., Ltd., 2012,12,28.

[2] jinmingji. On the leader's moral quality[J]. Baidu Library, 2011,12,18.

[3] luxiaosi. Construction enterprise project manager's professional moral standard[J]. Real estate e-NET, 2013, 3,11.

[4] zhangyong. Analysis of ways to project management Department style construction of leading cadres $[\mathrm{J}]$. modern commerce, 2011, (36).

[5]【Thought reports】The manager's idea (1) [J]. Douding network, $2011,8,18$
[6] huangjing 、 wangxiaojin. Empirical Analysis of Construction Project Manager Ability and Quality [J]. Sichuan construction science research, 2006,10, (5).

[7] luowenbiao 、 quyiyong 、 linzhijian. Brief discussion on the training mode of Project Manager [J]- commercial era 2005, (5).

[8] hanyan, fanjimei、 hanjing. Who will be an outstanding project manager-- On selection and training of Project Manager[J]Project management techniques 2004(7).

[9] guanyuhuan. On the selection and training of construction project manager talents[Conference Papers]-2005.

[10] miaoyanyan. Training and selection of project managers should adhere to both management and technology[J]- Higher Architectural Education 2003,12(2) 